\title{
Binding, verbinding en ontbinding
}

Citation for published version (APA):

Duijst, W. (2017). Binding, verbinding en ontbinding. Maastricht University. https://doi.org/10.26481/spe.20170317wd

Document status and date:

Published: 17/03/2017

DOI:

10.26481/spe.20170317wd

Document Version:

Publisher's PDF, also known as Version of record

\section{Please check the document version of this publication:}

- A submitted manuscript is the version of the article upon submission and before peer-review. There can be important differences between the submitted version and the official published version of record.

People interested in the research are advised to contact the author for the final version of the publication, or visit the DOI to the publisher's website.

- The final author version and the galley proof are versions of the publication after peer review.

- The final published version features the final layout of the paper including the volume, issue and page numbers.

Link to publication

\footnotetext{
General rights rights.

- You may freely distribute the URL identifying the publication in the public portal. please follow below link for the End User Agreement:

www.umlib.nl/taverne-license

Take down policy

If you believe that this document breaches copyright please contact us at:

repository@maastrichtuniversity.nl

providing details and we will investigate your claim.
}

Copyright and moral rights for the publications made accessible in the public portal are retained by the authors and/or other copyright owners and it is a condition of accessing publications that users recognise and abide by the legal requirements associated with these

- Users may download and print one copy of any publication from the public portal for the purpose of private study or research.

- You may not further distribute the material or use it for any profit-making activity or commercial gain

If the publication is distributed under the terms of Article $25 \mathrm{fa}$ of the Dutch Copyright Act, indicated by the "Taverne" license above, 
mr .dr. W.L.J.M. Duijst-Heesters Faculteit der Rechtsgeleerdheid

\section{Binding, verbinding en ontbinding}




\section{Rede}

\section{Uitgesproken bij de aanvaarding van het ambt van bijzonder hoogleraar forensische geneeskunde en gezondheidsstrafrecht aan de faculteit der rechtsgeleerdheid van de Universiteit Maastricht op 17 maart 2017}

Geachte mw. de rector magnificus, geachte medische en juridische collega's, geachte aanwezigen,

'Ik zweer/beloof dat ik de geneeskunst zo goed als ik kan zal uitoefenen ten dienste van mijn medemens. Ik zal zorgen voor zieken, gezondheid bevorderen en lijden verlichten. ${ }^{\prime 1}$ Met deze Eed van Hippocrates vangt het arts-zijn aan. Deze eed verwoordt het verlangen, dat jonge mensen die kiezen voor het beroep van arts, delen. Deze jonge mensen hebben allen het verlangen om mensen te helpen en bij voorkeur beter te maken. Zij lijden aan het redderssyndroom.

De drang om mensen te helpen is wat de medische studenten bindt. ledereen die de geneeskundestudie doet wordt beschouwd als 'een van ons'. Alle anderen worden beschouwd als 'zij, die het niet echt goed begrijpen'. Toen wij, de medische studenten van de Vrije Universiteit in Amsterdam in de jaren tachtig samen met tandheelkundestudenten college hadden, beschouwden we de tando's, zoals wij ze noemden, als de buitenstaanders. De tando's hielden zich immers bezig met slechts een zeer beperkt deel van het lichaam en wij, de medisch studenten, met het gehele lichaam. Op dat moment beseften wij nog niet dat wij ons later als specialist ook maar met een beperkt deel van de mens of een beperkt deel van de geneeskunde bezig zouden houden. Ook wij zouden uiteindelijk steeds meer van steeds minder weten. De tandheelkundestudenten hadden dat eerder begrepen dan wij.

Wij, geneeskundestudenten, begrepen elkaar; dat schiep een band. In de groep geneeskundestudenten was er één student die zichzelf buiten de groep stelde. Die ene student beweerde glashard dat hij geneeskunde ging studeren omdat hij veel geld wilde verdienen. Een geluid als uiting van afschuw ging door de werkgroep. 'Hoe kon hij dat zeggen?' Jaren later blijkt dat deze student het allemaal nog niet zo slecht had bekeken. Sinds de invoering van de marktwerking in de zorg, is geld verdienen een belangrijke drijfveer voor de zorg geworden. En geld leidt onvermijdelijke tot fraude. Op dit moment

\footnotetext{
${ }^{1}$ Eed van Hippocrates, 400 v. Chr. Hippocrates liet zijn leerlingen van het Asklepeion op het eiland Kos de belofte afleggen. De Eed wordt heden ten dagen in gemoderniseerde vorm afgelegd door artsen bij hun afstuderen.
} 
zijn er zelfs 'onafhankelijk deskundige artsen', ook wel ODA's genoemd, nodig om de fraude, die voortvloeit uit geldzucht in de zorg te ontmaskeren. ${ }^{2}$ Maar dat even terzijde.

De gewone geneeskundestudenten begrepen elkaar destijds en dat is ook vandaag de dag nog zo. Zij vormen een front. Er zijn dokters en er is de rest van de wereld. De rest van de wereld bestaat uit alle andere professionals en ook de patiënten. Dat de patiënten ook behoren tot de rest van de wereld blijkt als we praten over 'shared decision making tussen arts en patiënt'. ${ }^{3}$ Bij de aankondiging van de wetswijziging van de Wet geneeskundige behandelingsovereenkomst over shared decision making is de eerste kritiek dan ook direct: 'De kenniskloof tussen arts en patiënt is zo groot dat van gezamenlijke beslissingen geen sprake kan zijn'. ${ }^{4}$ Uiteindelijk kan de patiënt dus alleen maar doen wat de arts juist vindt. Gaat de mondigheid van de patiënt verder dan kritische vragen stellen over de voorgestelde behandeling, dan voorspelt de arts dat het niet goed gaat aflopen met de patiënt. Het overlijden van een eigenwijze patiënt kan leiden tot tuchtrechtelijke ${ }^{5}$ en strafrechtelijke procedures tegen de betrokken hulpverleners. ${ }^{6}$ De strafrechter gebruikt in het Millecam ${ }^{7}$ vonnis de volgende woorden: 'De koppigheid van de patiënt kan niet het laatste woord hebben'. ${ }^{8}$ De Millecam zaak is in hoger beroep en cassatie gegaan en het oordeel over wie het laatste woord heeft, is wat getemperd, ${ }^{9}$ maar het geworstel tussen patiënt en arts is zeker niet ten einde. Nog pregnanter komt dit probleem naar voren als de patiënt zwanger is en eigenwijs. ${ }^{10}$ De oproep tot het uitvoeren van een gedwongen keizersnede om het ongeboren kind te redden van de koppigheid van de moeder wordt in die gevallen gehoord. ${ }^{11}$ En daarmee werd de mondigheid van de patiënt ten grave gedragen en de wet terzijde geschoven.

\footnotetext{
${ }^{2}$ Convenant inzet onafhankelijk deskundige arts bij signalen en verdenkingen van fraude in de zorg, Stcrt. 2016, nr. 57996.

${ }^{3}$ J. Legemaate, Nieuwe verhoudingen in de spreekkamer: juridische aspecten achtergrondstudie rvzadvies 2013.

${ }^{4}$ F. Bosch, Y. Smulders, Durf als dokter leiding te nemen, Medisch Contact 12 aug 2015. E. Fenema, Shared decision making is drijfzand, Medisch Contact 2016, nr. 45.

${ }^{5}$ C.N.M. Renckens, F.S.A.M. van Dam en R.A.P. Koene, Strenge tuchtrechtelijke maatregelen in de zaak-Millecam: belangrijke jurisprudentie voor het aanscherpen van de gedragsregels door de wetenschappelijke verenigingen en de KNMG, Ned Tijdschr Geneeskd. 2006;150:1847-51.

${ }^{6}$ ECLI:NL:RBAMS:2009:BI7422.

${ }^{7}$ Millecam was een bekende comedienne die toen zij borstkanker kreeg koos voor alternatieve zorg en overleed. Rapport IGZ, De zorgverlening aan S.M., 2004.

${ }^{8}$ ECLI:NL:RBAMS:2009:BI7422.

${ }^{9}$ ECLI:NL:GHAMS:2010:BO7707. ECLI:NL:HR:2013:BY4876.

${ }^{10}$ ECLI:NL:TGZRAMS:2013:12. ECLI:NL:TGZRAMS:2013:13.

${ }^{11}$ K. de Groot, 'Een nieuw ontdekte procedure: de "Actio Caesarea"', NJB 2015/1190, afl. 25, p. 1656-1657; Reactie op het voorstel van De Groot: A. de Ruiter, 'Gelijke aanspraak op lichamelijk integriteit', NJB 2015/1191, afl. 25, p. 1658-1659; Praktijkperikel; Mag een arts gedwongen sectio uitvoeren in het belang van het kind?, Medisch Contact 2015, p. 1484 (auteur niet vermeld). W.Duijst,e.a. Actio caesarea - Een gevaarlijke oplossing voor een niet-bestaand probleem, NJB nov. 2016.
} 
De artsen vormen een front en begrijpen elkaar en zoeken elkaar op. De binding tussen artsen onderling is een dubbele binding. Het zijn soortgenoten die elkaar opzoeken, die dezelfde taal spreken en die hetzelfde hogere doel nastreven. Dat aangaan van die dubbele binding met elkaar maakt dat er weinig ruimte is voor verbinding met anderen. Studenten van andere studies komt de geneeskundestudent slechts tegen op de studentenflat en in de kroeg. In het eerste geval gaan de gesprekken over wie zou moeten schoonmaken, maar dat niet heeft gedaan (en ook niet zal gaan doen). In het tweede geval weet ik niet waar de gesprekken over gaan. Ik heb namelijk niet meer dan twee kroeggangen gehaald en ben toen afgehaakt. Maar zij die wel vaker acte de presence hebben gegeven in het café wisten destijds evenmin waar de gesprekken over gingen en nu zeker niet meer.

Die andere soort studenten en wetenschappers ontmoeten elkaar dus niet als vanzelfsprekend. Die ontmoeting moet geforceerd worden. Tijdens mijn studie geneeskunde ben ik de confrontatie met de andere student 'aangegaan'. Alhoewel, confrontatie is wel een groot woord. Zonder daar een duidelijke reden voor te hebben, heb ik een bezoek gebracht aan de rechtenfaculteit van de Vrije Universiteit. Vol verbijstering heb ik daar rondgelopen en de 'andere species' begluurd. Begluren is het juiste woord, want ik heb met niemand gepraat en ik ben ook geen collegezaal binnen geweest. Ik heb mij alleen vertwijfeld afgevraagd wat een mens bezielde om rechten te gaan studeren. Daar zijn, op dat moment, viel pas tien jaar later op zijn plaats, toen de onbedwingbare behoefte op kwam om kennis te vergaren die viel buiten het medische domein. Achteraf bekeken moet ik mezelf beschouwen als een vrije radicaal. Niet alle elektronen waren blijkbaar benut. En dat vraagt om verbinding. Verbinding met andere disciplines stuit altijd op enige weerstand, niet in de laatste plaats van mijzelf.

Ondanks mijn eigen keuze voor de rechtenstudie, is weerstand tegen een echte verbinding met het recht nog lang gebleven. De weerstand bestond uit verzet tegen de totaal andere manier van denken van juristen en vooral tegen het strafrecht. De eerlijkheid gebiedt mij te zeggen dat ik niet geloof in straffen en dat maakt mijn binding met het strafrecht ambivalent. En juist in dat strafrecht heb ik mijn plek gevonden en dan nog in het gezondheidsstrafrecht, een deel van het strafrecht dat zich begeeft op het medische terrein. Dat is een terrein met veel lading. Artsen en juristen komen van twee verschillende planeten, spreken verschillende talen en hebben hun eigen regels. Doorgaans kunnen zij niet al te goed met elkaar overweg. Die regels die door artsen en juristen gehanteerd worden, botsen en die botsingen overstijgen de moeilijkheidsgraad van de hogere regeling die boven de lagere regeling gaat of specialis die gaat voor de generalis.

Het gezondheidsstrafrecht is het strafrecht op het terrein van de gezondheidszorg. De vraag die zich opdringt of strafrecht op het gebied van de gezondheidszorg wel zin heeft. Het strafrecht zou een functie kunnen vervullen in het vaststellen van het normstellend kader. ${ }^{12}$

${ }^{12}$ HR 19-02-1963, NJ 1963, 512 (Verpleegstersarrest). HR 12 maart 2013, ECLI:NL:HR:2013:BY4876 (Millecam-zaak). 
Ik ben er ten diepste van overtuigd dat de normen binnen de medische wereld duidelijk zijn en als artsen en verpleegkundigen de normen van hun beroep niet begrijpen, nadat die normen er jarenlang ingehamerd zijn, zullen zij die normen ook niet gaan begrijpen als het strafrecht die normen benadrukt. Overigens ben ik wel van mening dat een arts die de normen van zijn beroep niet begrijpt (en niet wil begrijpen) en/of deze normen op grove wijze schendt, uit zijn ambt gezet moet kunnen worden en bij ernstige overtredingen gestraft moet worden.

Verbinding tussen de geneeskunde en het strafrecht leidt tot enerzijds gezondheidsstrafrecht en anderzijds tot forensische geneeskunde. Verbinding met iets of iemand vraagt voor een deel om het loslaten van eigen waarden en doelen. Voor artsen die zich op het vlak van de forensische geneeskunde begeven, betekent dit dat oude waarden als 'genezen' en redden verlaten moeten worden. Het kenmerk van de forensische arts is namelijk dat hij altijd te laat komt. De mens die hij ontmoet is of al gedetineerd, verkracht, neergestoken, geslagen of overleden. Er is niets meer te genezen en niets meer te redden. Het vak van forensisch arts doet een beroep op een kwaliteit die niet of nauwelijks wordt aangeleerd in de medische opleiding en evenmin genoemd wordt in de Canmeds. ${ }^{13}$ Forensisch artsen zijn artsen die meester zijn op het gebied van de machteloosheid. Forensisch artsen komen in actie als de meeste artsen het strijdtoneel (hebben) verlaten.

Forensische geneeskunde is een vak dat geneeskunde en strafrecht met elkaar in verbinding brengt. Forensisch artsen 'lenen' als het ware de waarden van het strafrecht.

Onafhankelijkheid en onpartijdigheid en bijdragen aan een eerlijk proces zijn voor de forensisch artsen een 'way of being'. Aan de basis van het handelen van de forensisch arts liggen de mensenrechten zoals die neergelegd zijn in het Europees verdrag voor de rechten van de mens en de fundamentele vrijheden.

Verbinding met een andere discipline, in dit geval het strafrecht, schept verantwoordelijkheden naar die discipline. De verantwoordelijkheid bestaat daaruit dat de forensisch arts zijn plaats kent in het grotere systeem van strafrechtspleging. Bij forensische geneeskunde is niet de geneeskunde het hogere doel, maar het strafrecht. Om die reden kunnen forensisch artsen dan ook andere handelingen verrichten dan behandelend artsen. Forensisch artsen kunnen handelen zonder de expliciete toestemming van een betrokkene, omdat zij handelen op grond een wettelijke (strafrechtelijke) regeling. Enkele voorbeelden: In de Wegenverkeerswet is de bevoegdheid om bloed af te nemen bij een vermoeden van rijden onder invloed opgenomen. ${ }^{14}$ In het Wetboek van Strafvordering een bevoegdheid neergelegd om gedwongen bloed af te nemen indien het vermoeden bestaat dat bij het plegen van een delict een infectieziekte wordt overgedragen. ${ }^{15}$ Daarnaast kan een verdachte worden bevolen om mee te werken aan afname van materiaal voor DNA-

\footnotetext{
${ }^{13} \mathrm{http}: / /$ www.cczorg.nl/coaching/canmeds-assessment/canmeds-rollen/

${ }^{14}$ Art. 8 WVW 1994.

${ }^{15}$ Art. 151e Sv.
} 
onderzoek. ${ }^{16}$ Nieuw is de regeling van gedwongen bloedafname na het plegen van een delict onder invloed van drank of drugs. ${ }^{17}$

De basis van de forensische geneeskunde is en blijft echter de geneeskunde en dat betekent dat forensisch artsen in hun werk het belangrijke principe van 'primum non nocere' niet zullen verlaten. Zij zullen hun patiënt, of hij nu levend of dood is, geen schade doen, ook niet als zij een opdracht krijgen, ook niet als zij een bevel krijgen. Vertaald naar de praktijk houdt dit in dat het forensisch geneeskundige handelen altijd een wettelijke basis en een redelijk doel moet hebben. Ontbreekt de wettelijke basis, maar acht de officier van justitie een bloedafname of een medisch onderzoek van belang of geeft hij daar zelfs opdracht toe, dan moet een weigering van de forensisch arts volgen. Bestaat er een wettelijke basis, maar ontbreekt een redelijk doel, dan moet de forensisch arts weigeren om mee te werken aan een onderzoek. Een voorbeeld kan deze laatste stelling verduidelijken. Stel dat een agent door een boze arrestant in het been wordt gebeten. In dat geval ontstaat er doorgaans angst voor een HIV-besmetting bij de agent. De agent en zijn leidinggevende willen dan dat bloed wordt afgenomen bij de arrestant om te weten te komen of de arrestant HIV-positief is. Een begrijpelijke vraag. Het antwoord op die vraag wordt doorgaans iets minder goed begrepen. Degene die kans maakt om besmet te worden is niet degene die gebeten is, maar de bijter. ${ }^{18}$ Het is de taak van de forensisch arts om dit uit te leggen, ook als dit op onbegrip stuit. Het is de taak van de forensisch arts om in dit geval de bloedafname te weigeren, omdat dit handelen geen redelijk doel dient. Ook hier komt de eed van Hippocrates weer om de hoek kijken. De eed verplicht de arts om ook onder druk stand te houden. ${ }^{19}$

Een verzoek van een officier van justitie of een rechter aan een forensisch arts zal ten alle tijden worden getoetst aan de wat de World Medical Association en de KNMG van elke arts verwacht. Zo zullen forensisch artsen handelen als onafhankelijke professionals, zij zullen handelen met compassie en respect voor de menselijke waardigheid. De forensisch arts zal ook niets doen waarvan zijn patiënt niet op de hoogte is. ${ }^{20}$ De beroepscodes van de forensisch arts maken dat de arts dan ook geen worsteling kan en mag aangaan met een gedetineerde om bloed af te nemen of sporen te verzamelen.

Door de verbinding tussen strafrecht en forensische geneeskunde ontstaat niet alleen voor de forensisch arts een verantwoordelijkheid, maar ook voor het strafrecht. Het strafrecht heeft niet alleen een ontvangende functie. Het strafrecht heeft een belangrijke kritische functie. De forensisch arts werkt samen met tactische en forensische opsporing en levert een product aan de officier van justitie. In de samenwerking mag en moet de politie een

\footnotetext{
${ }^{16}$ Art. $151 c$ Sv.

${ }^{17}$ Art. 55d Sv.

${ }^{18}$ RIVM Landelijke richtlijn prikaccidenten, www.RIVM.nl.

${ }^{19}$ Eed v. Hippocrates: Ik ken mijn verantwoordelijkheid voor de samenleving en zal de beschikbaarheid en toegankelijkheid van de gezondheidszorg bevorderen. Ik maak geen misbruik van mijn medische kennis, ook niet onder druk.

${ }^{20}$ WMA International Code of Medical Ethics, www.wma.net.
} 
kritisch constructieve houding aannemen. En officieren van justitie mogen (en moeten dat mijns inziens ook) als 'consumenten' van de forensische geneeskunde kritisch zijn. Die kritische houding zou er zeker moeten zijn ten opzichte van de verslagen die worden aangeleverd ten behoeve van het strafrecht en ten opzichte van lijkschouwverslagen. Een kritische houding van de officier van justitie komt de kwaliteit van de verslagen en daarmee de strafrechtspleging ten goede.

Voorwaarde voor een echte verbinding is dat er een vertrouwensrelatie bestaat tussen het openbaar ministerie, politie en de forensisch arts, zodat kritische vragen ten aanzien van elkaars handelen gesteld kunnen worden. Partijen begeven zich daarbij niet op elkaars professionele terrein. ${ }^{21}$ Een officier van justitie kan als sparringpartner voor de forensisch arts optreden in het geval van een overlijden, maar de forensisch arts neemt uiteindelijk de beslissing over natuurlijk of niet natuurlijke dood. ${ }^{22}$ Een forensisch arts adviseert over het al dan niet doen van een sectie, maar de officier van justitie neemt uiteindelijk de beslissing. ${ }^{23}$

De forensische geneeskunde staat niet alleen in verbinding met de politie en het openbaar ministerie maar ook met de zusterdisciplines, zoals de forensische pathologie en de forensische radiologie, de forensische odontologie en de forensische antropologie. De forensisch arts moet op de hoogte zijn van ontwikkelingen in de zustervakken en bereid zijn om laagdrempelig om een advies te vragen. Bij ingewikkelde casus moet worden samengewerkt. Samenwerken is niet zo zeer een optie als wel een verplichting om te komen tot een optimale strafrechtpleging. De rol van de forensisch arts is het leggen van de verbinding en het houden van overzicht en adviseren en aansturen van het forensisch medische proces.

In het geheel van verbindingen zou de forensisch arts idealiter een kernfiguur moeten zijn. Die kernfiguur gaat verbindingen aan met alle partijen. Die verbindingen leveren een nieuw geheel op. Die verbindingen kunnen niet anders dan enige spanning veroorzaken. Die spanning zal vooral voelbaar zijn op de grenzen van deskundigheidsgebieden. Want waar ligt de grens tussen forensische geneeskunde en forensische pathologie? In de landen om ons heen bestaat die grens niet. ${ }^{24}$ In Nederland wel, dat geeft te denken. En wanneer is een lijk zover vergaan dat het lijk het domein van de forensische geneeskunde en pathologie heeft verlaten en is binnengetreden in het domein van de forensische antropologie? Op dat soort vragen is geen antwoord te geven en als er al een antwoord is dan is dat antwoord oninteressant. Op het grensgebied van de pathologie en de antropologie is maar één oplossing mogelijk en dat is samenwerking. Door de expertise op twee vlakken met elkaar te verbinden ontstaat een geheel dat meer is dan de som der delen.

\footnotetext{
${ }^{21}$ W. Duijst, Editorial Expertise en recht, 2017, nr. 1.

${ }^{22}$ Art. 7 WLB.

${ }^{23}$ Art. 73 WLB.

${ }^{24}$ W. Duijst, C. Woudenberg, V. Soerdjabalie, De lijkschouw en sectie beschouwd, Rapport NFI 2016.
} 
Een zekere gezonde spanning tussen disciplines kan geen kwaad. Gezonde spanning brengt de discussie op een hoger niveau en maakt dat het advies dat uiteindelijk aan het strafrecht wordt gegeven een kwalitatief goed advies is, waarin verschillende aspecten worden belicht. Spanning die leidt tot elkaar de vliegen afvangen of erger nog uitspraken doen buiten het eigen expertisegebied schaadt het strafrecht.

Om de Forensisch arts zijn positie in te laten nemen tussen openbaar ministerie en zusterdisciplines is een adequate opleiding van de forensisch arts noodzakelijk. Het opleidingsplan zoals dat is aangeboden aan het College van geneeskundige specialismen biedt daar een solide basis voor. ${ }^{25}$

Waar gaat deze binding en verbinding toe leiden? Het is mogelijk teleurstellend, maar dit gaat maar tot een ding leiden en dat is de dood. De dood geeft doorgaans geen aanleiding tot al te vrolijke gedachten. Rond 600 v.Chr. schets de Griekse dichter Homerus een beeld van de dood als 'het grootst denkbare kwaad'. ${ }^{26}$ Homerus spreekt over de dood als 'verschrikkelijk, beangstigend' en als 'de diepten van Hades waaruit geen weg terug is.' Enkele eeuwen later komt Epicurus ${ }^{27}$ met een geruststellende meededeling: 'Als wij er zijn, is de dood niet, en als de dood er is, zijn wij niet.' Seneca ziet de dood, net als de rede, als zinvol onderdeel van de kosmos. ${ }^{28}$ De rede wijst ons de weg om het goede van de dood onder ogen te zien. Epictetus voegt daar aan toe "Je hebt toch de vermogens gekregen om op een goede manier om te gaan met de dood? Gevoel voor eigenwaarde, moed, uithoudingsvermogen. Ja, je zult sterven, maar moet je daarom ook jammeren?". ${ }^{29}$

Hoewel ook in de huidige tijd de dood de enige zekerheid is in het leven, wordt de dood doodgezwegen. In de medische opleiding wordt de dood niet of nauwelijks besproken. Uiteraard wordt er gesproken over dodelijke ziekten, maar dan alleen als 'nog dodelijk'. Dodelijk betekent dat de medische wetenschap nog niet hard genoeg zijn best heeft gedaan (en niet genoeg geld heeft gekregen) om een oplossing te vinden voor de ziekte. De dood is daarmee een symbool geworden van het falen van de arts. En als de arts faalt, dan zwijgt hij en kijkt de andere kant op.

En dat is ook precies wat er gebeurt als de dood intreedt. De arts doet niets meer, is niet meer geïnteresseerd. De desinteresse is zo groot dat als de gedachte opkomt dat de dood is ingetreden, de arts soms zelfs niet de moeite neemt om de dood vast te stellen of een poging daartoe te doen. ${ }^{30}$ Dat leidt dan tot situaties waarin het lijk ineens 'auw' zegt en de arts gaat praten over schijndood. Schijndood betekent letterlijk dat het lijkt of een persoon dood is. De oorzaak is vaak onderkoeling of intoxicatie. Schijndood kan alleen achteraf

\footnotetext{
${ }^{25}$ Opleidingsplan FMG forensisch arts, zelfstandig profile.

${ }^{26} \mathrm{~J}$. Choron, Death and Western thought. The first comprehensive study ever published on the great philosophers.

${ }^{27} 341-271$ v Chr.

${ }^{28} 4$ v. Chr. - 65 n. Chr. Seneca, De lengte van het leven, Athenaeum 2012.

${ }^{29} 60$ - 117 n. Chr. Epictetus, Verzameld werk, Athenaeum 2011.

${ }^{30}$ Centraal Tuchtcollege voor de gezondheidszorg 21 maart 2013, TGZCTG:2013:YG2742.
} 
worden bepaald. Wie dood lijkt en waarbij niet naar signalen wordt gezocht dat deze stelling onjuist zou kunnen zijn, gaat uiteindelijk alsnog dood door de handelingen (of het ontbreken daarvan) die volgen. Alleen bij die persoon die dood lijkt en tijdig een signaal afgeeft dat de zaken iets anders liggen, wordt de schijndood ontdekt.

De gemiddelde arts maakt het niet zo bont dat hij zelfs niet de dood vaststelt. De gemiddelde arts pakt een stethoscoop en een lampje, niet dat daarmee lege artis de dood kan worden vastgesteld, maar toch het is meer dan om de hoek kijken en zeggen: 'Ik heb het al gezien'. Een uitdrukking die de vraag oproept wat deze arts dan heeft gezien. Het feit dat iemand dood is kan de arts namelijk niet zien. De dood is, juridisch gezien, het stadium waarin de hersendood is ingetreden. ${ }^{31}$ En hersendood is niet vast te stellen met een lampje. Volgens de forensische literatuur is het enige zekere teken van de dood een verregaande staat van ontbinding. ${ }^{32} \mathrm{Nu}$ is het niet direct de bedoeling dat de arts wacht met het vaststellen van de dood tot een verregaande staat van ontbinding is ingetreden, maar iets meer dan het zwaaien met een lampje zou wenselijk zijn. Na het lampje is het tijd voor de overlijdenspapieren. De papieren krijgen aanzienlijk meer aandacht dan de overledene, of eigenlijk de vermoedelijk overledene. De drive om te papieren in te vullen is zo groot dat artsen zelfs een verklaring van natuurlijk overlijden invullen en vervolgens op het Bformulier voor de statistiek aankruisen dat het gaat om een niet-natuurlijk overlijden.

Dat moet anders. De komende jaren moet de dood 360 graden aandacht gaan krijgen in een soort amfitheater, waarin alle aspecten goed bekeken kunnen worden. De dood heeft diverse gezichten en enkele daarvan wil ik belichten.

\section{De juridische kant van de dood}

De juridische kant van de dood gaat over de positie van het lijk, lichamelijke integriteit na de dood en de grenzen van lijkschouw. Duidelijk is uit de literatuur, waarin artsen en juristen lijnrecht tegenover elkaar staan, dat het laatste woord over de positie van het lijk niet gesproken is. ${ }^{33}$ Mocht nu het idee ontstaan dat artsen en juristen hun eigen kamp betrekken; dat is niet zo. De artsen en juristen vormen gezamenlijk kampen en die kampen spreken elkaar tegen. De discussies gaan over de vraag of het lijk lichamelijke integriteit heeft. En als dat al zo is of lichamelijke integriteit betekent dat de betrokkene volledig kan (of kon) beschikken over zijn eigen lichaam. Of betekent lichamelijke integriteit dat het

\footnotetext{
${ }^{31}$ H.A.H. Van Till-d'Aulnis de Bourouill, Doodgaan, wat is dat?, Utrecht: Bohn Scheltema Holkema 1970, p. 4.

${ }^{32}$ B. Madea, Handbook forensic medicine, Wiley 2014, p. 51-53.

${ }^{33}$ Kamerstukken II 1978-79, 15 463, nr. 2, p.5-6. R. Kraan, K. Das, M. Rurup en U. Reijnders, Invasief postmortaal onderzoek vraagt wetgeving, NJB 2016, nr. 43. W. Venderink en J.C.J. Dute, Juridische aspecten van postmortale radiologie, Ned. Tijdsch Geneesk. 2016;160:D969. W. Duijst en T. Naujocks, Over lijken, De dood en daarna, vanuit juridisch-medisch perspectief, Maklu 2015, p. 2223.
} 
lichaam ook na de dood wordt beschermd, zelfs als de betrokkene dat niet wil (of wilde)? En als er zelfbeschikking over het eigen lijk bestaat, wie gaat dan na de dood vertellen wat de overledene zou hebben gewild? Met andere woorden: bestaat zoiets als 'veronderstelde toestemming'?

Een ander probleem is dat ondanks dat meer dan 147.000 keer per jaar een lijk wordt geschouwd, of zou moeten worden geschouwd, zo langzamerhand niemand meer lijkt te weten wat een lijkschouw is. Behandelend artsen en forensisch artsen buitelen over elkaar heen. Een ook hier geldt dat het niet noodzakelijkerwijs zo is dat de forensisch artsen het in hun eigen beroepsgroep eens zijn met elkaar en hetzelfde kan worden gezegd over de behandelend artsen. De meningen lopen uiteen van 'schouwen is alleen kijken' (en dus ook niet uitkleden), tot 'natuurlijk moet je bloed afnemen bij een lijk'. Onduidelijkheid alom die de professionaliteit en eenheid in het vak niet ten goede komen. Het hoeft dan ook geen verbazing te wekken als een natuurlijke dood achteraf toch een vergiftiging blijkt te zijn of als ouders twijfels hebben over de zelfdoding van hun kind. ${ }^{34}$ En ook politici hoeven niet verbaasd te zijn als uit onderzoek naar voren komt dat dodingsdelicten worden gemist. ${ }^{35}$

En dan het begrip natuurlijke en niet-natuurlijke dood. In de Wet op de Lijkbezorging zijn deze termen bepalend voor de vraag wie de lijkschouw mag verrichten. Is het een natuurlijke dood dan kan de behandelend arts de lijkschouw verrichten. Is het een nietnatuurlijke dood dan moet de lijkschouw worden verricht door de forensisch arts. Het vreemde aan deze wettelijk regel is dat al voorafgaand aan de schouw een vooronderstelling over natuurlijke of niet-natuurlijke dood wordt gemaakt. Gezien de grote gevolgen van de keuze tussen natuurlijke of niet-natuurlijke dood, zou het voor de hand liggen dat duidelijk is wat deze termen betekenen. Aan de hand van enkele voorbeelden wil ik aantonen dat de logica ten aanzien van deze termen ver te zoeken is. Als een mens een grote hoeveelheid alcohol drinkt en ten gevolge van acute intoxicatie sterft, is dat een nietnatuurlijke dood. Als diezelfde mens over dat intoxicatieproces 30 jaar doet en uiteindelijk sterft aan levercirrose, dan heet het een natuurlijke dood. Als een man een ongeval krijgt, verlamd raakt aan het onderlichaam, een katheter geplaatst krijgt en 30 jaar later een infectie krijgt door die katheter is dat een niet-natuurlijke dood. En als een kind sterft nadat de arts de tube heeft verwijderd, maar de spierverslappers heeft 'door laat lopen', dan heet dat volgens de kinderartsen een natuurlijke dood en volgens de kinderchirurgen en forensisch artsen een niet-natuurlijke dood. ${ }^{36}$ Als een bacterie het lichaam binnendringt met dodelijk gevolg, heet dat een natuurlijke dood. Als een mens door een hond gebeten wordt en daardoor een infectieziekte oploopt dan heet dat een niet-natuurlijke dood. Als een bij een mens steekt en de dood treedt in, dan...?

\footnotetext{
${ }^{34}$ Nabestaanden Dasha eisen dossier justitie op, Metronieuws, 16 oktober 2016. R. Kraan, K. Das, M. Rurup en U. Reijnders, Invasief postmortaal onderzoek vraagt wetgeving, NJB 2016, nr. 43.

${ }^{35}$ W. Duijst, V. Soerdjabalie en C. Woudenberg, De lijkschouw en sectie beschouwd, NFI 2016.

${ }^{36}$ Richtlijn Medische beslissingen rond het levenseinde bij pasgeborenen met zeer ernstige afwijkingen, knmg 2013. Wrevel door nieuwe richtlijn baby-euthanasie, Trouw 28/06/13.
} 
Het nut van dit soort discussies is mijns inziens uiterst gering. Waar het om zou moeten gaan is of de dood na adequaat onderzoek afdoende is verklaard en of de arts die erbij betrokken is zich toetsbaar opstelt. Dus als de arts de tube heeft verwijderd, of als de arts het leven van een demente bejaarde heeft beëindigd, dan meldt hij dat. Met het melden stelt hij zich toetsbaar op en dat is een belofte van die de arts heeft gedaan bij het afleggen van de artseneed. ${ }^{37}$

De betiteling als natuurlijk of niet-natuurlijk is nauwelijks relevant en dient alleen de statistieken. Voor het vervaardigen van statistieken over doodsoorzaken is adequaat postmortaal onderzoek nodig. En zelfs als het onderzoek adequaat of zelfs extensief is, hoeft het resultaat daarvan niet door te klinken in de statistieken. Neem nu bijvoorbeeld de moord- en doodslagstatistieken. Al jarenlang daalt het aantal moorden en doodslagen in Nederland, ook in 2014, het jaar waarin de MH17 naar beneden werd gehaald. Wie een persoon doodt, pleegt een moord, die wordt geregistreerd als zodanig. ${ }^{38}$ Wie 298 mensen doodt, waaronder 196 Nederlandse ingezetenen, ${ }^{39}$ verwerft met zijn daad geen plaats in de statistieken.

De juridische kant van de dood gaat ook over verbinding en verplichting. Al vele jaren geleden heeft Nederland het Europees Verdrag voor de Rechten van de Mens ondertekend. Een van de belangrijkste mensenrechten is artikel 2, het recht op leven. Duidelijk is dat, als een persoon is overleden, het recht op leven (al dan niet vrijwillig) is prijsgegeven. Het is al jarenlang vaste jurisprudentie van het Europese hof voor de rechten van de mens (EHRM) dat de staat niet alleen een ontijdige dood van een burger moet proberen te voorkomen, maar tevens de verplichting heeft om een overlijden adequaat te onderzoeken. ${ }^{40}$ Voor het onderzoeken van overlijdens dient de staat een adequaat systeem in te richten. De verplichting om een overlijden te onderzoeken drukt zwaarder op de staat als het gaat om een gewelddadige dood of als de overledene een kwetsbaar mens is. ${ }^{41}$ De sectie is volgens het EHRM een belangrijk instrument om de doodsoorzaak vast te stellen. Een sectie dient plaats te vinden als dit kan bijdragen aan het vinden van de doodsoorzaak. ${ }^{42}$ Bij de uitspraken van het EHRM wordt verwezen naar het United Nations Model Autopsy Protocol

\footnotetext{
${ }^{37}$ Eed v. Hippocrates: Ik zal de geneeskundige kennis van mijzelf en anderen bevorderen. Ik erken de grenzen van mijn mogelijkheden. Ik zal mij open en toetsbaar opstellen.

${ }^{38}$ P.P.M. Harteloh, Veranderingen in de doodsoorzakenstatistiek 2013-2015. Aantal moorden in 2014 spectaculair gedaald, Elsevier dec. 2014.

${ }^{39}$ Chronologie van de MH17-ramp in Oost-Oekraïne, Nu.nl, Gepubliceerd: 21 juli 2014 .

${ }^{40}$ EHRM 17 juli 2014, no. 47848/08, § 132 (Centre for Legal Resources on Behalf of Valentin Câmpeanu t. Romania). EHRM 14 maart 2013, no. 28005/08, § 186 (Salakhov en Islyamova t. Ukraine). EHRM 17 januari 2002, no. 32967/96, Calvelli en Ciglio t. Italië, EHRC 2002/22. EHRM 9 april 2009, no. 71463/01, Šilih t. Slovenië.

${ }^{41}$ HR 28 februari 2012, ECLI:NL:HR:2012:BU6088.HR 5 juli 2011, ECLI:NL:HR:2011:BP6141, ECLI:NL:PHR:2011:BP6138 en ECLI:NL:HR:2011:BP6144.

${ }^{42}$ EHRM 14 december 2010, no. 74832/01, § 93 (Mižigárová t. Slovakia). EHRM 17 juli 2014, no. 47848/08, §§ 25, 146-147 (Centre for Legal Resources on Behalf of Valentin Câmpeanu t. Roemenie). Raad van Europa 2006, p. 42.
} 
en de European Autopsy rules, waarin is neergelegd hoe en in welke gevallen een dood moet worden onderzocht. ${ }^{43}$ Ook de European Autopsy Rules heeft Nederland ondertekend, maar dan wel met een zeer bijzondere voorwaarde. Nederland heeft een voorbehoud gemaakt voor het artikel, waarin vermeld staat wat de indicaties zijn voor een sectie en dat artikel was nu precies de reden waarom de Rules zijn opgesteld. Polderen en rekening houden met iedereen is een aardige gewoonte. Net zolang polderen totdat er geen afspraak meer over blijft, is de dood in de pot.

De polderdrift is ook bij de procedure rondom het overlijden van een minderjarige toegeslagen. De zogeheten NODO (nader onderzoek doodsoorzaak overleden minderjarigen) procedure was oorspronkelijk bedoeld om gevallen van kindermishandeling uit te filteren. De reden voor het tot stand brengen van het wetsvoorstel was gelegen in een onderzoek van Van Kuyvenhove, waaruit bleek dat artsen een verklaring van natuurlijk overlijden afgaven terwijl zij wisten dat dat feitelijk niet juist was. ${ }^{44}$ Het oorspronkelijke plan was, dat na het overlijden van een minderjarige het overlijden gemeld zouden worden bij de forensisch arts en dat indien de doodsoorzaak onduidelijk was, een onderzoek zou worden ingesteld. Vervolgens zou worden bepaald of sprake was van een natuurlijke of een nietnatuurlijke dood. Na ruim een jaar is de NODO-pilot, die leidde tot een goede samenwerking tussen forensisch artsen en kinderartsen en het vinden van doodsoorzaken in ruim $75 \%$ van de gevallen, ${ }^{45}$ gestaakt. De uitkomst van de pilot was dat door de NODO geen gevallen van kindermishandeling werden gevonden. Het feit dat slechts $60 \%$ van de overleden kinderen werd gemeld bij de forensisch arts, werd niet meegenomen in de beoordeling van de resultaten van de pilot. Voor de snelle rekenaar: $40 \%$ werd niet gemeld en de vraag is, waarom niet? Is het mogelijk dat daar de gemiste levensdelicten in zitten? Het antwoord van het ministerie van V\&J op de evaluatie van de NODO was dat de interesse eindigde, het ministerie van VWS de procedure overnam en de naam wijzigde in NODOK, nader onderzoek doodsoorzaak overleden kinderen. De NODOK mocht in de toekomst alleen nog uitgevoerd worden met de schriftelijke toestemming van beide ouders. ${ }^{46}$ Door deze beslissing van het ministerie van VWS heeft het ministerie het doel van de Wet op de lijkbezorging verlaten. Het doel was niet langer het uitfilteren van misdrijven, maar het doel was de verwerking van het verlies door de ouders. De stellingname van het ministerie VWS gaat lijnrecht in tegen de European Autopsy Rules, maar daarover had Nederland al een voorbehoud gemaakt. Het ministerie wil dat forensisch artsen zich zo min mogelijk

\footnotetext{
${ }^{43}$ Recommendation 1159 (1991) of the Parliamentary Assembly of the Council of Europe on the Harmonisation of Autopsy Rules. EHRM 27 juni 2000, no. 21986/93, §§ 106-109 (Salman t. Turkije). EHRM 13 oktober 2010, no. 45661/99 (Carabulea t. Roemenië).

${ }^{44}$ M.M. Kuyvenhoven, C.F. Hekkink \& Th. B. Voorn, Overlijdensgevallen onder 0-18 jarigen door vermoede mishandeling: naar schatting 40 gevallen in 1996 gebaseerd op een enquête onder huisartsen en kinderartsen, Ned. Tijdschr Geneesk. 1998, 14 november; 142 p. 2515-2518.

${ }^{45}$ NODO-Evaluatieonderzoek Onderzoek naar de effectiviteit van de NODO-procedure in het achterhalen van de aard van het onverwacht en onverklaard overlijden van minderjarigen in Nederland 2013, p.17.

${ }^{46}$ Brief minister VWS dd. 30 juni 2016, 97404-150828-PG.
} 
bemoeien met de NODOK. Nogal een ingewikkeld standpunt aangezien in de Wet op de lijkbezorging, overigens door het ministerie VWS zelf mee ondertekend, de verantwoording voor de NODOK-procedure is neergelegd bij de forensisch arts.

Samenvattend kan worden vastgesteld dat al jarenlang bekend is dat het systeem van lijkschouw in Nederland nauwelijks adequaat te noemen is. ${ }^{47}$ Hieraan heeft Nederland sinds 2016 een inadequaat systeem voor onderzoek van het overlijden van een minderjarige toegevoegd. Moet daarmee worden vastgesteld dat de Nederlandse overheid akkoord gaat met begraven of cremeren van burgers zonder de doodsoorzaak te weten? Ik spreek hier vandaag de hoop uit dat Nederland zich zodanig verbonden voelt aan het EVRM dat dit leidt tot de ontwikkeling van een adequaat systeem van lijkschouw. De verwachtingen ten aanzien van de taskforce lijkschouw die is ingesteld door het ministerie van V\&J zijn hoog. ${ }^{48}$

Bijzondere overlijdens vragen bijzondere aandacht. Een van de grote thema's in onderzoek moet de komende jaren het overlijden onder verantwoordelijkheid van de overheid zijn. Onder overlijden onder verantwoordelijkheid van de overheid wordt verstaan het overlijden in strafrechtelijke detentie, in een BOPZ-instelling of tijdens aanhouding. Het onderzoek naar dergelijke overlijdens moet medische en strafrechtelijke aandacht krijgen. Elk overlijden in detentie, in een BOPZ-instelling of tijdens aanhouding is in beginsel een onverwacht overlijden en vraagt om die reden om een antwoord op de vraag of het overlijden verklaard kan worden. Elk overlijden onder die omstandigheden vraagt om een adequaat onderzoek dat een antwoord kan geven op de vraag van de nabestaanden: 'Waaraan is mijn geliefde overleden?'. Elk overlijden vraagt om een evaluatie van het overheidshandelen, niet alleen het overlijden van de Russische vluchteling Dolmatov. ${ }^{49}$

Vele jaren geleden toen wij een aanvang maakten met dit onderzoek door de suïcides in detentie te onderzoeken, ${ }^{50}$ werd ons als onderzoekers te verstaan gegeven dat nader onderzoek naar overlijdens in detentie niet noodzakelijk was. De verantwoordelijkheden voortvloeiend uit art. 2 en 3 EVRM brengen niet alleen met zich mee dat een individueel overlijden moet worden beoordeeld. Ook epidemiologisch onderzoek is noodzakelijk, om patronen te herkennen en te leren van overlijdens. Eenmalige onderzoeken kunnen leiden tot de onjuiste conclusie dat problemen in de overdracht van medische gegevens en in het nemen van verantwoording voor de evaluatie van het suïcidegevaar problemen zijn die slechts incidenteel voorkomen. Dergelijke eenmalige onderzoeken kunnen ook tot maatregelen, zoals het maken van een tuchtrechtelijk verwijt aan goedbedoelende

\footnotetext{
${ }^{47}$ Recherche Advies Commissie, Rapport Forensische Geneeskunde: een vak apart. 11. C. Das \& W. Duijst, 'Veel lijkschouwers ondeskundig', MC 2007, p. 154-156. Rapport Gezondheidsraad, De forensi- sche geneeskunde ontleed, 2013. W. Duijst, Tussen dood en begraven, NJB 2015, 1510.

${ }^{48}$ Brief van de minister van veiligheid en justitie aan de Tweede Kamer 2016, 34550 VI 29.

${ }^{49}$ IGZ, Rapport: Het overlijden van Alexander Dolmatov 2014.

${ }^{50}$ E. Thoonen, S. van der Gaauw, N. Korthals Suïcide in detentie \& EVRM, Maklu 2011.
} 
verpleegkundigen ${ }^{51}$ leiden. Die maatregelen gaan er niet in resulteren dat de verpleegkundigen hun verantwoordelijkheid meer gaan nemen, want dat deden ze al (eigenlijk te veel). Dergelijke tuchtrechtelijke maatregelen tegen individuele verpleegkundigen gaan er ook niet toe leiden dat de kwaliteit van de zorg verbetert, want die zorg is een teamtaak en het in de samenwerking in het team waar het probleem ligt.

Ontwikkelingen in het overheidshandelen kunnen alleen worden geëvalueerd als een wetenschappelijke compilatie van die overlijdens wordt gemaakt. Die compilatie moet in vrijheid en dus zonder inmenging van de overheid tot stand kunnen komen. De inmenging van de overheid mag ook niet bestaan uit het simpelweg niet vrij willen geven van de benodigde gegevens voor wetenschap onderzoek.

Een transparante opstelling van overheidsinstellingen kan verrassende resultaten opleveren. Het onderzoek van mijn onderzoeksgroep op dossiers van Rijksrecherche heeft geleid tot aandacht voor de medische kant van de aanhouding bij verwarde personen. Die kant kon in het onderzoek naar individuele overlijdensgevallen niet aan de orde komen omdat daarin te veel de aandacht was gevestigd op de mogelijke schuld van de politieagent. De vooronderstelling was namelijk dat de overlijdens waren veroorzaakt door de nekklem. ${ }^{52}$ Uit het onderzoek blijkt dit vaak niet het geval te zijn, omdat de nekklem is veel gevallen van overlijden bij aanhouding niet werd toegepast. En wat als de uitkomst was geweest dat de nekklem wel de voornaamste oorzaak is van overlijden bij aanhouden, dan moet de overheid dat toch willen weten?

\section{Medische en biologische kant van de dood}

De medische kant van het overlijden gaat over het proces van overlijden. Wie kan zeggen wat het proces van doodgaan is? Wie weet hoe het bewustzijn van de stervende is? Wat hoort en ervaart de stervende? Wanneer sterft een lichaam? De hoeveelheid vagen maakt duidelijk dat de wetenschapper wakker is. Dat wakker zijn heeft nog geen vorm, maar gaat het zeker krijgen de komende jaren. De verbinding met de neuro(psycho)logen ligt hierbij voor de hand.

De biologische kant van wat er na de dood gebeurt, is iets waar we liever niet over nadenken. De biologische kant van de dood is de ontbinding. Ontbinding is weinig charmant. Ontbinding is vies en ontbinding stinkt. En er zijn maar weinig mensen die het kunnen waarderen als de kleine bewoners van de aarde zich te goed doen aan een stoffelijk overschot. Waarom zou een wetenschapper zich bezig willen houden met dit proces? Het antwoord op die vraag is gelegen in de taak van de forensisch arts en de veronderstelde

\footnotetext{
${ }^{51}$ Regionaal Tuchtcollege gezondheidszorg Den Haag 26 augustus 2014 ECLI:NL:TGZRSGR:2014:97 en ECLI:NL:TGZRSGR:2014:96.

52 Inspectie V\&J, De Nekklem, Thematisch onderzoek naar aanleiding van toepassing van een nekklem in hetzuiderpark in den Haag 2015.
} 
competentie van die arts. Bij een lijkschouw is een van de kernvragen aan de forensisch arts: Wat is het tijdstip van overlijden?. Of met andere woorden: Sinds wanneer is het een lijk? Als het antwoord op die vraag is gegeven, dan kunnen we misschien ook antwoord geven op de vraag wie er mogelijk betrokken is geweest bij de dood. Het tijdstip van overlijden kan mede bepalend zijn voor wie er als verdachte wordt aangemerkt. Het tijdstip van overlijden kan bepalend zijn voor 'in welke bak van vermisten we moeten zoeken' als er ergens een niet geïdentificeerde dode wordt gevonden. Het belang wordt duidelijk als in strafrechtelijke uitspraken wordt verwezen naar deskundigen en de door hen gebruikte onderzoeksmethoden. Uit onderzoek blijkt dat naar mate het tijdstip van overlijden verder terug in de tijd ligt, het vaststellen van dat tijdstip van overlijden steeds moeilijker wordt. ${ }^{53}$ Het steeds moeilijker worden, weerhoudt deskundigen er niet van om uitspraken te doen over het tijdstip van overlijden. ${ }^{54}$ De forensische wetenschap heeft dringend behoefte aan evidence based onderzoek om tot een nauwkeurige bepaling van het tijdstip van overlijden te komen. Inmiddels zijn gevalideerde ontbindingsscores en ontbindingsatlassen gemaakt ten einde de fases van ontbinding te kunnen koppelen aan het tijdstip van overlijden. ${ }^{55}$

Naast het ontwikkelen van de scoringsmethoden is in Den Ham een Pig Farm gestart. Een aantal studenten trotseert de stank en de beestjes en doen observaties aan ontbindende biggetjes. Voor wie nu ongerust wordt: ze zijn niet doodgemaakt voor het onderzoek; de biggetjes waren al dood en zijn toen voor het onderzoek gebruikt. Dat onderzoek had niet gekund zonder de verbinding met het dierenartsencentrum in Den Ham. Op de Pig Farm zijn inmiddels mooie resultaten geboekt en de eerste plannen voor internationale uitbreiding en verdieping van het onderzoek zijn gemaakt. Het ligt in de lijn dat het onderzoek wordt uitgebreid met deskundigen op het gebied van bacteriologie en entomologie en een promotietraject ligt in het verschiet.

Nu hoor ik u denken: Gaat Nederland dan een body farm krijgen? Duidelijk is dat als wetenschappers iets moeten gaan zeggen over ontbinding in het Nederlandse klimaat, dat het wetenschappelijke onderzoek uiteindelijk ook zal worden uitgebreid naar onderzoek met menselijke stoffelijke overschotten. Daar is geen ontkomen aan. De eerste stappen in die richting zijn gezet door het $\mathrm{AMC}$ in samenwerking met ketenpartners en academische partners. ${ }^{56}$ Dat onderzoek met menselijke stoffelijk overschotten wordt alleen gedaan als er voldoende voorstudies zijn geweest en het zal plaatsvinden met de volledige geïnformeerde instemming van de betrokkene die zijn lichaam ter beschikking van de wetenschap heeft gesteld.

\footnotetext{
${ }^{53}$ Onderzoek Tamara Gelderman.

${ }^{54}$ T.Krap en W.Duijst, De postmortale tijdsbepaling als bewijsmiddel, EER 2015, nr. 1.

${ }^{55}$ M.A. van Daalen , D.S. de Kat, B.F.L. Oude Grotebevelsborg, R. de Leeuwe, J. Warnaar, R.J. Oostra, W.L.J.M. Duijst, An Aquatic Decomposition Scoring Method to Potentially Predict the Postmortem Submersion Interval of Bodies Recovered from the North Sea, J Forensic sciences March 2017.

${ }^{56}$ Arts begint begraafplaats voor rottingsonderzoek, Medisch contact februari 2017.
} 
Mijn ideaalplaatje zou zijn een onderzoeksplaats waar zowel boven als onder de grond ontbinding van lichamen kan worden bestudeerd. De onderzoeksplaats moet ruimte bieden aan promovendi en stagiaires van $\mathrm{HBO}$ instellingen en universiteiten. Een vergelijkbare onderzoeksplaats zou ook in andere landen kunnen worden geïnstalleerd ten einde de invloed van het klimaat op ontbinding te onderzoeken. Bij dat onderzoek zal altijd aandacht zijn voor de menselijke waardigheid en door dat te doen houdt de onderzoekende arts zijn beroep in ere en daarmee zijn we dan weer gekomen bij de Eed van Hippocrates. ${ }^{57}$

\section{Dankwoord}

Bij het einde van een rede hoort een dankwoord.

Mijn dank gaat uit naar het college van bestuur van de Universiteit Maastricht en de Raad van bestuur van de medische en de rechtenfaculteit voor het vertrouwen dat zij in mij hebben gesteld.

De gezamenlijke GGD-en en het NFI wil ik danken voor deze topsportbenoeming. Mijn functie wordt een balanceren tussen eerste en tweede lijn, tussen strafrecht en geneeskunde. Vanwege dat balanceren is er wel enige gelijkenis met Sanne Webers, de topturnster die de eerste gouden medaille op de Olympische spelen ooit veroverde met haar spectaculaire oefening op de evenwichtsbalk. Een tweede gelijkenis is dat ik net als zij een eindeloos vermogen heb om opnieuw op de balk te klimmen als ik eraf gevallen ben.

Speciale vermelding verdient de GGD ljsselland, ‘mijn' GGD. Jaren geleden ben ik daar gestart als forensisch arts en al bij mijn aanstelling werd mij gevraagd wat er kon worden gedaan om te voorkomen dat ik mij ging vervelen. Vanaf de allereerste dag heeft de GGD mij een onderzoeksaanstelling gegeven en die kans heeft mede de basis gevormd voor de ontwikkeling van wetenschappelijk onderzoek.

Onderzoek kan niet zonder een team. Het onderzoeksteam, mijn buitenfaculteit, bestaat al vanaf de dag dat ik de universiteit verliet om wetenschap te kunnen bedrijven. Het is een hecht team dat gaat voor het resultaat. Het is een onderzoeksteam waarin de leden elkaar ondersteunen, helpen en durven te bekritiseren. In dat team zal de mens altijd belangrijker zijn dan dat wat hij doet. Het is een team dat zich uitbreidt en niet alleen met volwassene. 'Ons' eerste kind is geboren en het tweede is op komst. Dank voor wat jullie toevoegen aan mijn leven.

Medische en juridische collega's, dank voor alle leermomenten. Ik hoop met jullie samen te werken aan een brug tussen strafrecht en de medische wereld.

${ }^{57}$ Eed v. Hippocrates: Ik zal zo het beroep in ere houden. 
Familie en vrienden, heerlijk dat jullie er zijn. Een deel van jullie is hier niet omdat ik hier sta in een toga. Jullie zijn er in tijden dat we elkaar nodig hebben om vreugde en verdriet te delen.

En dan komen we tot de kern van mijn bestaan, Jaap en Saenthip, Jan, Eefke. Als gezin hebben wij vaak gekeken naar 'As good as it gets'. Om geheel verschillende redenen moeten wij lachen om die film. De een om de scene met de hond, de ander om de beschrijving van vrouwen en de ander om het neurotische gedrag van Jack Nicholson. Wat wij allemaal herkennen is de beschrijving van Helen Hunt over de 'dawn patrol'. Wij weten als geen ander wat zij bedoelt en niet alleen 'at dawn'. Vandaag zijn jullie allemaal hier, omdat wij met elkaar het antwoord hebben gevonden op die ene vraag van jack Nicholson: ' What if this is as good as it gets?'. Ik voel mij vereerd dat ik jullie moeder mag zijn.

En tenslotte komen we dan aan bij de man. Aart, jij wilde het liefst zelf bepalen wat ik over jou ging zeggen. Helaas, volgzaamheid is een woord dat niet in mijn woordenboek voorkomt. Jij hebt een bijzondere prestatie geleverd. Je bent namelijk de enige levende man die het voor elkaar heeft gekregen om mijn 100\% aandacht te krijgen. Vanaf de dag dat ik je ontmoette ben jij mijn lotsbestemming. Met jou is er geen bindingsangst, geen verbindingsangst en geen ontbindingsangst.

Ik heb gezegd.

17 maart 2017 